\title{
A Study on Brand Extension and Cannibalization of Color Cosmetics
}

\author{
Man Seok Song ${ }^{1 *}$, Yun-Jae $\mathrm{Cho}^{2}$, Mi Ju Yim ${ }^{3}$ \\ ${ }^{1}$ Department of Advertising and PR, Tong Myong University, Busan, Korea \\ ${ }^{2}$ School of Start-up \& Assets Convergence (Marketing), Changwon National University, Changwon-si, Gyeongsangnam-do, Korea \\ ${ }^{3}$ College of Business Administration, Dong-A University, Busan, Korea
}

\author{
"Corresponding author: Man Seok Song, \\ Department of Advertising and PR, Tong \\ Myong University, 428 Sinseon-rom, Nam- \\ gu, Busan 48520, Korea \\ Tel.: +82516292051 \\ Fax: +82336292510 \\ Email: consulting89@hanafos.com
}

Received August 21, 2020

Revised November 23, 2020

Accepted December 01, 2020

Published December 30, 2020

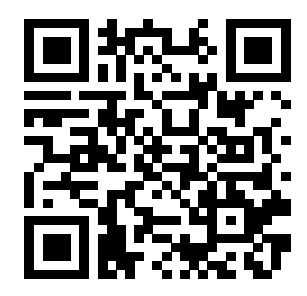

\begin{abstract}
Purpose: TIncorrect brand expansion could cause image failure of existing brands and create cannibalization among family brands. It could reduce sales and decrease market efficiency, bringing about a worst-case fatal loss scenario. Methods: This study used the Bass diffusion model, positioning map analysis, and cannibalization analysis by introducing a cross analysis to understand the cannibalization phenomenon within the field of color cosmetics. Specifically, we focused on subsidiaries of a big cosmetics company. We administered questionnaires to 286 female college students who used color cosmetics. We then performed a frequency analysis using the Statistical Package for the Social Sciences to carry out a demographic statistical analysis and biplot analysis. We also performed positioning map analysis and cross analysis to understand color cosmetics brand loyalty, transfer intention, breakaway rate, future market share rate, and the cannibalization phenomenon. Results: The Bass Diffusion Model for cannibalization analysis showed that cannibalization was present throughout all family groups. The cannibalization phenomenon happened only at MISSHA and A'fieu color cosmetics of Able C\&C cosmetics brand, according to positioning map analysis. All of the cross-analysis estimation alternatives exhibited a cannibalization phenomenon. Conclusion: These results hold implications for expanded brand portfolio performance measures in an intensely competitive market, launching new products, launching new brands in the new market, analyzing the market competition structure with competitive brands, and developing strategies to defend cannibalization.
\end{abstract}

Keywords: Color cosmetics, Cannibalization, Bass diffusion model, Positioning map analysis, Cross analysis

\section{Introduction}

색조화장품 시장은 대량 소비 시대에서 개인 맞춤형 소비 시대로 변화하는 구매 패턴의 변화에 따른 시장 재편의 강화가 급격히 요구 되는 가운데 트렌드에 민감한 소비자 증가와 함께 소비자의 니즈가 더욱 세분화됨에 따라 이를 충족하는 차별화된 컨셉의 신제품들이 지속적으로 출시되면서 화장품 전체 시장에서 색조화장품 시장은 높은 성장률을 유지하면서 그 비중이 더욱 증가하고 있어 화장품 모 기업은 패밀리 브랜드 포트폴리오 확장을 통해 화장품 시장점유율 증가와 함께 시장경쟁력 향상을 위해 보유 브랜드 포트폴리오 간 시
너지 효과를 창출하고자 새로운 컨셉의 패밀리 화장품 브랜드 확장 전략을 전개하고 있다.

브랜드 확장은 소비자들의 신제품 수용을 촉진할 뿐만 아니라 모 브랜드에 긍정적인 피드백을 제공하며 성공적으로 수행된 브랜 드 확장은 모 브랜드 자산 가치를 강화시켜 주기도 하여(Keller \& Aaker, 1992), 기존 브랜드와의 유통망 공유와 촉진 비용 효율성에 도 기여할 수 있는 장점(Morein, 1975)과 모 브랜드의 연상과 이미 지를 강화하고(Martinez et al., 2009), 후속 브랜드 확장에 대한 기 초를 마련해줄 뿐만 아니라(Kirmani et al., 1999) 모 브랜드의 인 지도를 바탕으로 소비자의 구매 행동에 지각된 불안을 감소시키고 
소비자의 구매 욕구를 촉진하는 효과를 얻을 수 있다.

그러나 본질적으로는 유사한 브랜드임에도 불구하고 서로 다른 브랜드인 것처럼 차별화하여야 하는 기업의 입장에서 자기시장잠식 을 고려하여 브랜드 차별화 전략을 추구해야 한다면 중요한 문제가 발생한다. 이때 차별화가 원래 목표한 것과 같이 이루어지지 못한 브랜드는 유사성의 문제로 자기시장잠식(cannibalization) 현상이 발생하게 되며(Song, 2020), 본래 브랜드가 가지고 있는 이미지나 소비자에게 전달하고자 하는 positioning 상의 위치가 달라지는 브 랜드에 치명적인 손실을 끼치게 될 수 있다(Loken \& John, 1993).

브랜드 확장은 많은 기업에서 성장 전략 근원으로 활용하고 있으 며(Tauber, 1988) 새로이 확장하는 브랜드뿐만 아니라 기존 브랜 드에도 많은 재무적 이익을 주게 되며(Collins-Dodd \& Louviere, 1999; Völckner \& Sattler, 2006) 모 브랜드와 확장 카테고리간의 유사성이 있을 때 브랜드 확장의 효율성이 더 높게 된다. 그러나 브 랜드 확장으로 인한 효율성은 높으나(Chu, 2005) 시장 경쟁우위를 위해 시도한 브랜드 확장이 반드시 성공하는 것이 아니라 $84 \%$ 가 실 패하게 되며(Tait, 2001) 브랜드 확장이 성공적으로 이루어졌더라도 $70 \%$ 정도는 일이 년 사이에 시장에서 사라지게 되는 실패 가능성도 높기 때문에 확장된 브랜드에 영향을 주는 요인에 대한 연구는 매우 중요하다(Lee \& Chang, 2007).

이와 같이 색조화장품 상품군에서 상품을 제공하는 기업이 잘못 된 브랜드 확장으로 소비자에게 비차별적이며 서로 비슷한 편익을 제공하고 있다면 기존 제품의 시장 실패를 가져올 수도 있으며 매출 액의 감소와 함께 시장효율이 저하되는 경우가 발생할 수도 있어 자 기시장잠식 현상이 발생하는 최악의 상황을 맞을 수 있다(Buday, 1989; Loken \& John, 1993; John et al., 1998).

본 연구는 색조화장품 시장에서 잘못된 브랜드 확장으로 인한 자 사의 기존 브랜드와의 자기시장잠식 및 브랜드 희석효과(Tauber, 1988; Aaker \& Keller, 1990)에 관한 연구로 지난해 국내 색조화장 품 시장에서 가장 경쟁력이 높은 아모레퍼시픽 화장품 그룹의 이니 스프리 색조화장품과 에뛰드하우스 색조화장품 그리고 에이블씨엔 씨 화장품 그룹의 미샤 색조화장품과 어퓨 색조화장품을 연구대상 으로 설정하여 브랜드 확장 효율과 자기시장잠식에 대한 분석을 위 해 Bass 확산모형 분석과 positioning map 분석 그리고 교차분석을 통하여 확장된 패밀리 브랜드 간의 자기시장잠식과 경쟁 브랜드와 의 시장잠식 그리고 시장경쟁력 측정을 위한 연구를 수행하는데 그 목적을 두고 있다.

사실 브랜드 확장으로 인한 역효과는 상당한 중요한 문제임에도 불구하고 접근성의 어려움으로 자기시장잠식에 관한 대부분의 국 내 연구는 컴퓨터와 통신판매시장(Shin, 1997; Lee et al., 1996) 에서 제한적으로 이루어지고 있으나 다른 산업 분야에서는 수행된 연구가 거의 없으며, 화장품 산업 분야에서는 최근에 이르러서야 Song(2020)에 의해 자기시장잠식의 연구가 시작되고 있는 실정이 다. 본 연구에서는 색조화장품 브랜드 시장에서 자기시장잠식을 분
석할 수 있는 분석방법론을 고찰하며 이의 새로운 분석 모형을 제시 하고자 한다.

연구의 접근방법으로는 Shin(1997)과 Song(2020) 등이 수행한 자기시장잠식 연구를 위해 도입한 Bass (1969)확산모형을 도입하 여 Table 2 와 같은 결과를 도출하였으며, Bass 확산모형이 제공하 지 못하는 것을 보완하고 분석된 결과를 검증하기 위해 Song (2020) 이 제안한 positioning map 분석을 실시하여 각 평가대안 브랜드의 유사성과 선택속성의 차별화 정도를 Table 3 과 Table 4 의 좌표 값을 가진 Figure 1과 같이 시각적으로 도출하여 자기시장잠식의 확인과 검증을 할 수 있으며 Table 5 와 Table 6 과 같은 교차분석에 의한 색 조화장품 브랜드에 대한 현재시장점유율과 미래시장점유율의 분석 과 함께 충성도와 브랜드 전환행렬 분석을 통하여 자기시장잠식의 분석과 Bass 확산모형 분석에 대한 검증도 함께 실시하고자 한다.

이러한 분석 결과는 색조화장품 시장에서 강력한 브랜드 포트폴 리오 구축을 위해 전개한 잘못된 패밀리 브랜드 확장전략으로 인 해 발생 가능한 자기시장잠식에 대한 정확한 분석과 자기시장잠식 의 정도에 대한 정보를 획득할 수 있어 시설투자 및 제반 운영에 필 요한 사업계획의 수립과 효율적인 투자 정책을 위해 필수적이며, Song (2020)이 제안한 것과 같이 시장경쟁우위를 위한 마케팅 비용 의 과도한 지출과 함께 매출액은 높은 성장률을 보이지만 영업이익 은 오히려 감소하고 있는 지금의 경영환경에서 수익구조 개선을 위 한 패밀리 브랜드 확장 전략을 수립하는 데 중점을 두어야 할 자료 로 활용 가능할 것이다.

\section{Methods}

\section{1. 연구대상 및 자료수집}

설문조사 대상의 표집은 2019년 10월 21일부터 12월 20일까지 색조화장품을 사용한 경험이 있는 부산지역 여대생을 대상으로 총 300 부의 설문지를 배부하였으며 그 중 측정 주요 변수의 응답 누락 과 복수 응답으로 인해 본 연구를 위한 분석을 실시하기에 불성실한 응답자를 제외한 총 286 부의 설문지를 사용하여 본 연구를 위한 실 증 분석을 실시하였다. 그리고 또 다른 자기시장잠식의 측정을 위한 방법으로 연구 대상 화장품 기업의 색조화장품의 매출액 자료를 이 용하여 Bass 확산모형 분석을 실시하였다.

\section{2. 측정항목 및 내용}

본 연구는 연구대상 색조화장품 브랜드에 대해 설문지법과 Bass 확산모형을 적용하였으며, 설문 문항은 색조화장품 이용 소비자 에 의한 자기시장잠식 측정을 위해 biplot 분석 측정 항목과 충성도 와 이탈률 그리고 신규고객 유입률 그리고 인구통계적 특성 등의 분 석을 위해 총 111 문항의 측정항목으로 구성되어져 있으며, 설문지 의 구성은 $\mathrm{AHP}$ 분석을 위한 쌍대비교 측정항목과 절대가치 측정 
을 위한 리커트 측정항목과 인구통계적 특성 측정을 위한 명목척도 와 서열척도 그리고 빈도분석 측정항목으로 이루어져 있다. 구체적 인 내용의 분석 결과는 Table 1, Table 2, Table 3, Table 4, Table 5 , Table 6, 그리고 Figure 1과 같다.

측정을 위한 평가영역은 선행연구로부터 4 개의 평가영역인 가격 특성(Kim, 2014; Kim \& Lee, 2008; Yu, 2016), 품질 특성(Kim \& Kim, 2004; Jeong et al., 2016; Lee et al., 2016), 디자인 특 성(Kim, 2014; Lee, 2013; Lee, 2016), 그리고 제품 특성(Park \& Chin, 2010; Kim \& Lee, 2008; Park \& Kwon, 2017)의 검증된 변 수 중 Figure 1 과 Table 4 에 제시된 것과 같이 본 연구에 맞게 조정 하여 16 개의 변수를 평가요소로 도입하였다.

\section{3. 분석방법}

급변하는 색조화장품 시장 경영환경에서 자사의 수익을 극대화하 고 강력한 브랜드 자산구축과 시너지 효과를 위해 전개한 브랜드 확 장 전략이 적합한 브랜드 포트폴리오를 구축하지 못하게 되면 예상 하지 못한 자기시장잠식 문제가 발생하여 시장효율의 저하가 발생 하는 상황을 맞게 된다(Song, 2020).

자기시장잠식은 마케팅 실무자 및 학자에게는 친숙한 개념이지 만 측정에 관한 구체적인 방법론에 관한 연구는 거의 없으며(Shin, 1997), 이를 측정하기 위한 합의된 개념과 표준화된 척도도 없다 (Lomax et al., 1997; Varshney, 2016). Moorthy \& Png (1992) 역시 신제품을 대상으로 하는 연구에서 수리적인 모형을 이용하여 입증하였으나 규범적인 조언만 하며 자기시장잠식을 어떻게 측정할 것인가에 대해 언급은 하지 않았다.

Chandy \& Tellis (1998)와 Nijssen et al. (2005)의 연구에서 제 시된 자기시장잠식의 이론적 배경을 도입하는 동시에 자기시장잠 식 개념의 정량적 분석을 위한 분석방법으로 Kim \& Park (2018)와 Kim \& Shin (2008) 그리고 Shin (1997) 등이 자기시장잠식 분석 연구 수행을 위해 Bass 확산모형 분석 한 가지 계량적 분석방법만을 이용하여 연구를 진행하였으나 본 연구에서는 그들의 연구에서 제 공하지 못하는 것을 보완하고 분석 결과를 검증하는 차원에서 Song (2020)의 연구에서 제안한 Bass 확산모형 분석과 SPSS 통계패키지 프로그램 22.0 버전을 사용하여 positioning map 분석 그리고 교차 분석에 의한 브랜드 전환행렬 분석 등의 세 가지 분석방법을 동시에 실시하여 색조화장품 시장에서의 자기시장잠식 방법에 대해 새로운 접근 방법을 제시하고자 한다.

따라서 본 연구를 위한 자기시장잠식 연구방법을 구체적으로 살 펴보면 아직 합의된 개념과 표준화된 척도가 없으나 다른 선행연구 분야에서 자기시장잠식을 측정하기 위해 도입한 연구방법인 Bass 확산모형의 적용을 위해 연구 대상 색조화장품의 매출액 시계열 자 료를 이용하여 Equation 1을 적용한 Bass 확산모형 분석을 실시하 고 Bass 확산모형이 제공하지 못하는 것을 보완하고 분석 결과를 검 증하는 차원에서 복수의 분석방법으로 Equation 2 를 적용한 biplot
분석을 이용한 positioning map 분석의 도입과 브랜드 전환행렬 분 석을 위한 교차분석도 동시에 도입하여 색조화장품 현재시장점유율 과 미래시장점유율 그리고 브랜드 전환율 분석을 통한 충성도 분석 을 실시하기로 한다.

본 연구를 수행하기 위해 사용할 설문서는 크게 세 가지 유형으 로 구성되는데, 첫째, 설문서 I은 색조화장품 소비자의 평가대안 색 조화장품 브랜드 선택속성 우선순위와 가중치를 파악하고자 쌍대평 가 설문 문항으로 구성되며, 둘째, 설문서 II는 확장된 패밀리 색조 화장품 브랜드간의 자기시장잠식 측정을 위한 biplot 분석을 적용하 는 positioning map 분석을 위해 Equation 2의 Fishbein (Fishbein, 1963)의 속성 만족도-중요도 모델을 적용하기 위한 설문 문항으로 설문서 I의 평가요소에 대한 절대평가의 측정 문항으로 구성하게 되 며, 셋째, 설문서 $\mathbb{I I}$ 은 교차분석을 수행하여 자기시장잠식을 파악하 기 위해 구성된 설문 문항과 인구통계적 분석을 위한 설문 문항으로 이루어져 있다.

\section{4. 자기시장잠식 분석을 위한 접근 방법}

자기시장잠식이란 브랜드 확장으로 인하여 신제품이 출시되면 서 동일시장에서 같은 기업에서 제공하는 기존 제품의 판매량이나 시장점유율을 빼앗는 것을 의미하며(Copulsky, 1976; Mason \& Milne, 1994), 이를 Lomax et al. (1997)는 신제품 출시 시 실제로 발생할 수 있는 가장 큰 위협으로 보았고, 신제품 개발 시 나뼌 영향 을 미친다고 하였으며(Mason \& Milne, 1994), Sullivan (1990)은 자기시장잠식과 대체효과의 관계를 자기시장잠식은 새롭게 출시하 는 상품이 기존제품과 대체관계가 있을 때에 발생하는 대체현상의 하위 개념이라고 하였다.

자기시장잠식을 측정하기 위한 합의된 개념과 표준화된 척도는 없으나(Varshney, 2016; Lomax et al., 1997), Reddy et al. (1994) 등은 자기시장잠식에 대해 총 카테고리 판매의 비율, 척도를 신제품 의 판매에서 파생된 매출의 비율, 기업 포트폴리오 내의 기존 제품 수준에서의 자기잠식, 그리고 모 브랜드가 경험한 판매 손실만을 연 구할 수 있다고 하였으며, Lomax et al.(1997) 등은 증감 분석, 구 매 테이블 복제 및 예상되는 시장점유율 변동으로부터의 편차 등을 이용하여 자기시장잠식을 측정하는 방식으로 이용하고 있다고 하였 다.

그러나 이러한 접근방법으로는 새로운 색조화장품 포트폴리오 브 랜드 확장을 준비하고 있는 화장품 기업에게는 새로운 패밀리 브랜 드 확장 전 자사의 자기시장잠식을 산출하여 이를 바탕으로 해당 기 업이 해당 사업에 얼마나 적극적으로 역량을 집중할 것인가를 분석 하는 것이 부족하기 때문에 기존의 측정방법으로는 기업에서 필요 로 하는 바를 충족시킬 수 없다.

본 연구에서는 자기시장잠식 측정을 위해 도입하고자 하는 접근 방법으로 시계열 자료를 이용하여 측정하는 Bass 확산모형 방법 (Shin, 1997)과 완벽한 시계열 자료가 없는 상황에서 Jamieson \& 
Bass (1989)와 Urban \& Hauser (1995)이 제안한 연구방법을 적극 수용하여 그들이 제안한 연구방법을 충족할 수 있는 교차분석을 이용 한 브래드 전환분석을 실시하고자 하며, 그리고 또 한 가지 보완적 분 석방법으로 positioning map 분석도 동시에 실시하고자 한다.

이때 소비자를 대상으로 positioning map 분석과 교차분석을 실시 할 때에는 반드시 동종 또는 유사한 상품의 사용 경험을 이용하여야 하며, 출시전략의 유사성도 고려하여 신중하게 진행하여야만 자기시 장잠식 분석이 가능하다.

Bass 확산모형 분석은 Equation 1의 수식과 함께 시장을 정의하는 방법으로 확산과정의 기본 메커니즘을 추출하여 확산이론의 토대를 구축하는 공헌을 하며 많은 연구자가 그들의 연구에 적용하고 있다. 본 연구에서는 Bass 확산모형 분석으로 도출된 색조화장품 자기시장 잠식 분석 결과에 대해 보완하고 검증하기 위한 방법으로 positioning map 분석(Song, 2020)도 동시에 실시하여 보다 나은 결과를 도출하 고자 한다.

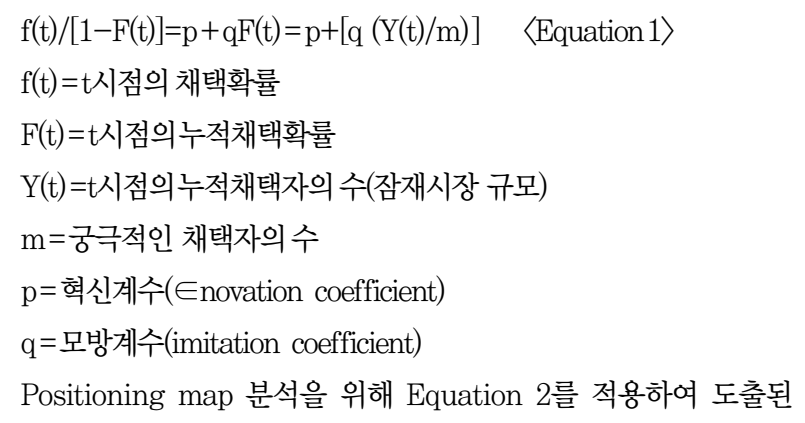

Figure 1, 그리고 Table 3 과 Table 4 와 같은 positioning map 분석
결과는 상대적으로 가까운 거리에 있는 평가요소 간 하나의 시장으 로 정의할 수 있으며 직접 경쟁 브랜드를 찾아내기 용이하다(You \& Choi, 2001). 유사성과 차별화의 문제를 해결하기 위해 positioning $\mathrm{map}$ 을 전략적으로 활용하게 되면 고객의 지각 속에 각 브랜드가 어 떻게 정위화되어 있는지를 알 수 있으며, 차별화가 원래 목표한 것과 같이 정위화되지 못한 브랜드는 유사성의 문제를 가지게 되어 자기시 장잠식 현상이 발생하게 됨을 알 수 있다(Song, 2020).

그리고 Song (2020)의 저가화장품 시장에서의 자기시장잠식에 관 한 선행연구에서 실시한 분석 방법과 같이 본 연구에서도 색조화장품 사용 소비자를 대상으로 교차분석을 이용한 브랜드 전환 행렬 분석 을 실시하여 Table 5 와 Table 6 과 같은 결과를 도출하여 positioning map 분석과 함께 Bass 확산 모델 분석을 적용한 색조화장품 자기시 장잠식 분석 결과에 대하여 보완과 검증도 하고자 한다.

$$
\mathrm{a}_{\mathrm{aj}}=\sum_{\mathrm{k}=\mathrm{j}}^{\mathrm{m}} \mathrm{e}_{\mathrm{wj}} \text { aij }\langle\text { Equation 2〉 }
$$

$w j=j$ 번째 측정항목 설명변수의 중요도

$a i j=$ 브랜드 $i$ 번째가중치경쟁력지표

\section{Results and Discussion}

\section{1. 일반적 특성}

본 연구 설문에 응답한 표본의 인구통계적 특성을 살펴보면 Table

\section{Table 1. Subject characteristics}

\begin{tabular}{|c|c|c|c|}
\hline Category & & Frequency $(\mathrm{N})$ & Percentage (\%) \\
\hline Gender & Female & 286 & 100 \\
\hline Age & Below 30 & 286 & 100 \\
\hline Job & Student & 286 & 100 \\
\hline \multirow{3}{*}{ Monthly visits } & Over 1 - Below 3 & 187 & 65.4 \\
\hline & Over 4 - Below 6 & 69 & 24.1 \\
\hline & Over 7 - Below 10 & 30 & 10.5 \\
\hline \multirow{6}{*}{$\begin{array}{l}\text { Monthly cosmetics } \\
\text { purchase amount }\end{array}$} & Below 10,000 won & 28 & 9.8 \\
\hline & 10,001 won $-30,000$ won & 127 & 44.4 \\
\hline & 30,001 won $-50,000$ won & 62 & 21.7 \\
\hline & 50,001 won- 100,000 won & 41 & 14.3 \\
\hline & 100,001 won $-150,000$ won & 20 & 7.0 \\
\hline & Over 150,001 won & 8 & 2.8 \\
\hline \multirow{5}{*}{ Monthly } & Below 3 million won & 121 & 42.3 \\
\hline & Income & 79 & 27.6 \\
\hline & $4,000,001$ won- $5,000,000$ won & 8 & 2.8 \\
\hline & $5,000,001$ won- $6,000,000$ won & 25 & 8.8 \\
\hline & Over $6,000,001$ won & 53 & 18.5 \\
\hline Total & & 286 & 100 \\
\hline
\end{tabular}


1 과 같으며, 색조화장품을 사용한 경험이 있는 부산지역 소재 D 대학 교과 $\mathrm{K}$ 대학교 그리고 $\mathrm{P}$ 대학교에 재학 중인 여학생을 대상으로 설문 조사하였다. 전체 표본은 286 명이며, 연령별 분포는 20 대로 구성됐 으며, 월평균 화장품 구매 비용은 10,000 원 이상에서 30,000 원의 구 간에서 127 명(44.4\%)으로 가장 높게 나타났으며, 월평균 150,000 원 이상의 구간이 8 명 $(2.8 \%)$ 으로 가장 낮게 나타났다. 가구당 월평균 소 득은 $3,000,000$ 원 미만이 121 명(42.3\%)으로 나타났으며, $6,000,000$ 원 이상의 소득자는 53 명(18.5\%)으로 파악되어져 나타났고, 이들 은 화장품 로드샵을 월평균 1 회 이상에서 4 회 미만 방문이 187 명 (65.4\%), 4 회 이상에서 6 회 미만 방문이 69 명 $(24.1 \%$ 그리고 7회 이 상에서 10회 미만이 30명(10.5\%) 정도로 방문하여 색조화장품을 구 매하거나 최신 색조화장품 트렌드 정보와 사용 방법에 대한 정보를 습득하는 것으로 나타났다.

\section{Bass 확산모형을 이용한 자기시장잠식 분석 결과}

Bass 확산모형은 신상품 수요예측뿐만 아니라 새로운 브랜드와 서 비스제에 대한 혁신의 확산과 개인적인 것이 아닌 전체시장의 수요를 거시적인 관점에서 예측하는 데 활용되고 있으며, 시계열 자료를 통해 상품이나 서비스가 전파되는 수준을 나타내는 것으로 판매중인 특정 브랜드의 신상품이 시간의 경과에 따른 연속적인 발전과정을 예측할 수 있으며, 새로운 상품이 시장에서 잠재 소비자에게 채택되어져 소비 되는 진행 과정을 나타낼 수 있다.

Equation 1에서 $\mathrm{p}$ 는 혁신계수를 나타내며, $\mathrm{q}$ 는 모방계수, $\mathrm{m}$ 은 포 화잠재시장규모를 나타내는 것으로 Bass 확산모형 분석 도입의 장점 이 된다. 포화잠재시장규모는 전체 시장규모의 예상 수이고 혁신계수 (p), 모방계수(q)는 보통 0 에서 1 의 값을 가지는 변수로서 본 연구를 위한 색조화장품 시장에서의 자기시장잠식 연구를 위한 혁신계수(p), 모방계수(q)의 추정은 연구대상 색조화장품 브랜드의 시계열 자료를 이용하여 Bass 확산모형으로 분석하였다.
$\mathrm{R}^{2}$ 는 Bass 확산모형 분석 결과에 대한 설명력과 적합도를 나타내는 것으로 $\mathrm{R}^{2}$ 값이 1 에 가까우면 설명력이 높으며 적합도 역시 높고 반 대로 0 에 가까우면 설명력이 낮을 뿐만 아니라 적합도 역시 낮다는 것 을 의미한다. 본 연구 수행의 결과인 Table 2 를 보면 $\mathrm{R}^{2}$ 값이 전부 0.9 이상으로 나타나 Bass 확산모형은 모두 설명력이 높으며 적합도 역시 높다.

아모레퍼시픽 화장품 그룹의 이니스프리 색조화장품의 경우 혁신 계수(p)는 0.00764 , 모방계수 $(\mathrm{q})$ 는 0.28768 , 포화잠재시장규모 $(\mathrm{m})$ 는 87936.55382 , 그리고 설명변수 $\left(\mathrm{R}^{2}\right)$ 는 0.94291 로 모형이 적합하게 도 출댔으며, 에뛰드하우스 색조화장품은 혁신계수(p)가 0.00412 , 모방 계수(q)는 0.32098 , 포화잠재시장규모(m)는 37861.08776, 설명변수 $\left(\mathrm{R}^{2}\right)$ 는 0.95382 로 모형이 적합하게 도출되었다.

에이블씨엔씨 화장품 그룹의 미샤 색조화장품의 혁신계수 $(\mathrm{p})$ 는 0.00502 , 모방계수 $(\mathrm{q})$ 는 0.27945 , 포화잠재시장규모 $(\mathrm{m})$ 는 61942.69358 , 설명변수 $\left(\mathrm{R}^{2}\right)$ 는 0.90781 로 모형이 적합하게 도출되었 으며, 어퓨 색조화장품의 경우 혁신계수(p)는 0.01066 , 모방계수(q)는 0.33462 , 포화잠재시장규모 $(\mathrm{m})$ 는 6727.76928 , 그리고 설명변수 $\left(\mathrm{R}^{2}\right)$ 는 0.98936 으로 도출되었다.

모방계수(q)가 혁신계수(p)보다 높은 것으로 나타난 이러한 분석 결 과는 상대적으로 진입 비율이 증가하는 것으로 볼 수 있으며 신제품 의 확산과 수용에 있어서도 중요한 의미를 가지게 되고 혁신계수가 모 방계수보다 작게 나타나 확산에는 영향을 미치지 못하며(Talukdar et al., 2002) 확장된 패밀리 색조화장품 브랜드 간의 자기시장잠식 가 능성이 발생할 수 있다. 저가화장품 시장에서 자기시장잠식을 연구한 Song (2020)의 연구 결과와 유사한 연구 결과를 보이고 있으며, 혁신 계수(p)의 경우에는 Sultan et al. (1990)의 연구 결과에서 도출된 평 균값보다 낮게 나타났으나 모방계수(q)가 제시된 평균값보다 높게 나 타나는 결과를 보이고 있어 이는 상대적으로 진입장벽이 낮은 화장품 산업계의 특수성을 고려하여야 할 것이다.

Table 2. Results of Bass diffusion model analysis of each brand for cannibalization measurement

\begin{tabular}{llccccc}
\hline \multicolumn{2}{l}{ Color cosmetics brands of evaluation alternatives } & $p$ & $q$ & $m$ & $R^{2}$ \\
\multirow{2}{*}{ Amore pacific cosmetic } & innisfree & 0.00764 & 0.28768 & 87936.55382 & 0.94291 \\
& ETUDE HOUSE & 0.00412 & 0.32098 & 37861.08776 & 0.95382 \\
\multirow{2}{*}{ Able C\&C cosmetic } & MISSHA & 0.00502 & 0.27945 & 61942.69358 & 0.90781 \\
& A'pieu & 0.01066 & 0.33462 & 6727.76928 & 0.98936 \\
\hline
\end{tabular}

Table 3. Evaluation of alternative value on the positioning map

\begin{tabular}{|c|c|c|c|c|}
\hline \multirow{2}{*}{\multicolumn{2}{|c|}{ Evaluation of alternative color cosmetics brand }} & \multicolumn{3}{|c|}{ Evaluation of alternative } \\
\hline & & Mind share & $\mathrm{X}$ axis & Y axis \\
\hline \multirow{2}{*}{ Amore pacific cosmetic } & innisfree & 0.267 & -0.140 & 0.130 \\
\hline & ETUDE HOUSE & 0.268 & -0.084 & -0.159 \\
\hline \multirow{2}{*}{ Able C\&C cosmetic } & MISSHA & 0.232 & 0.164 & 0.031 \\
\hline & A'pieu & 0.233 & 0.093 & 0.004 \\
\hline \multicolumn{2}{|l|}{ Total } & 1.000 & & \\
\hline
\end{tabular}




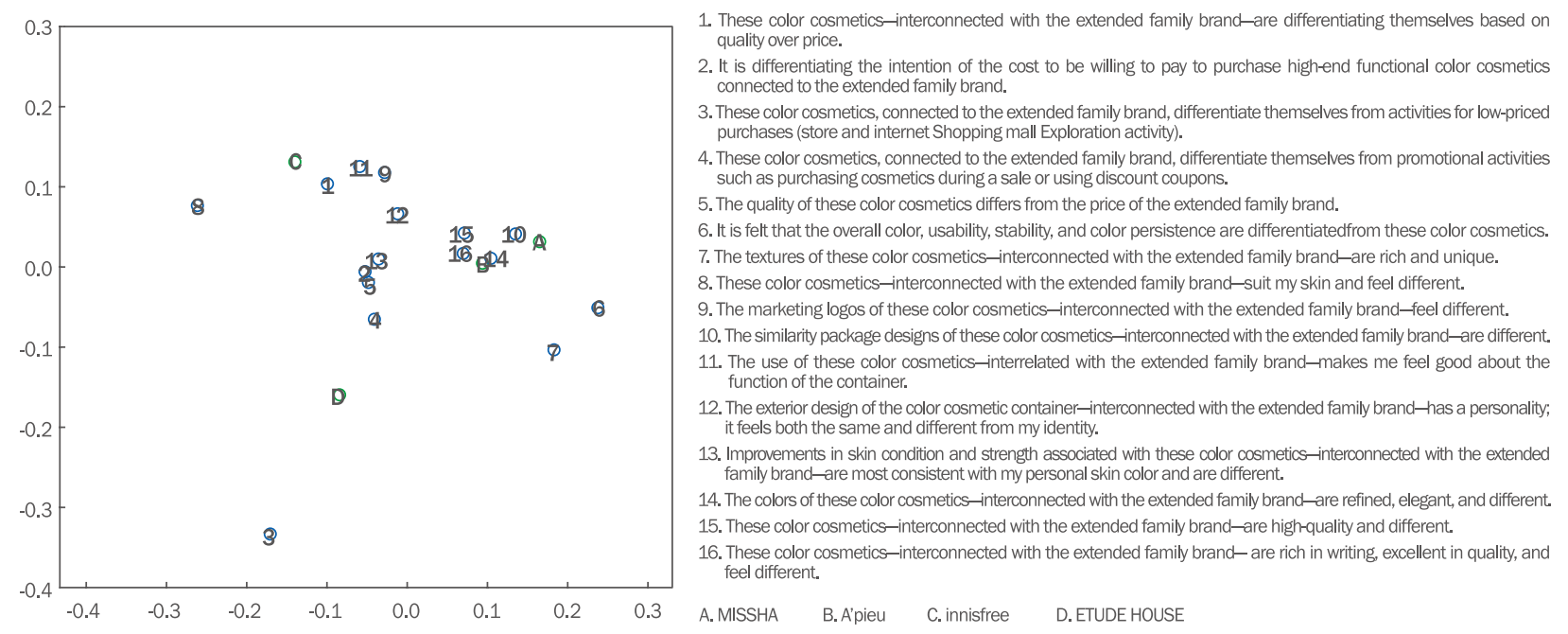

\section{Figure 1. Positioning map.}

In the positioning map analysis result, cannibalization is expected between MISSHA and A'pieu. Focusing on the two downward brands, evaluation factors $10,14,15$, and 16 are in close proximity. Due to the similarity of these evaluation factors, a cannibalization phenomenon is expected, and differentiation of evaluation factors is required. Refer to Table 3 and 4 for coordinate values of each evaluation attribute in the positioning map.

아모레퍼시픽 화장품 그룹의 이니스프리 색조화장품 경우 에뛰드 하우스 색조화장품보다 혁신계수(p)가 1.85 배 높은 것으로 나타났으 며, 모방계수(q)의 경우는 에뛰드하우스 색조화장품이 1.12 배 높은 것으로 나타났다. 이러한 연구 결과는 이니스프리 색조화장품이 새 로운 색조화장품 출시 당시에 높은 판매율의 성장을 보일 것이나 그 이후로는 에뛰드하우스 색조화장품에 비해 상대적으로 판매율이 낮 아질 수밖에 없다. 그리고 에뛰드하우스 색조화장품의 혁신계수 가 치가 이니스프리 색조화장품보다 낮게 나타나 제품의 판매율 상승 기대는 다소 늦게 천천히 나타날 것이며, 에이블씨엔씨 화장품의 미 샤 색조화장품과 마찬가지로 포화잠재시장규모 $(\mathrm{m})$ 가 현재 시장규모 보다 작게 되면 신규채택자의 수도 감소하기 시작하는 자기시장잠식 도 예상된다.

에이블씨엔씨 화장품 그룹의 어퓨 색조화장품의 경우 미샤 색조화 장품보다 혁신계수(p)가 2.12배 높은 것으로 나타났으며, 모방계수 (q) 역시 1.20 배 높은 것으로 나타났다. 이러한 결과는 어퓨 색조화 장품이 새로운 색조화장품 출시 시 높은 판매율의 성장을 보일 뿐만 아니라 그 이후에도 지속적인 성장 가능성이 예측된다. 그리고 미샤 색조화장품의 혁신계수 가치가 어퓨 색조화장품보다 상대적으로 낮 게 나타나 새로운 색조화장품의 판매율 상승 기대는 어퓨 색조화장 품보다 늦게 나타나게 될 것이며, 포화잠재시장규모 $(\mathrm{m})$ 가 현재 시장 규모보다 작게 되면 신규채택자의 수도 감소하기 시작하는 자기시장 잠식이 예상된다.

\section{Positioning map 분석을 이용한 자기시장잠식 분석 결과}

본 연구의 색조화장품 브랜드 평가대안과 평가요소에 대한 자기 시장잠식 분석 결과는 Figure 1 과 Table 3 그리고 Table 4에 제시 된 것과 같다. 입력 자료는 설문 응답자가 4 개의 색조화장품 브랜드 에 대해 16 개의 평가요소 속성별로 평가한 개별 색조화장품 소비자 의 평가요소에 대한 쌍대평가와 절대평가의 산출된 값을 biplot 분 석을 위한 입력 자료로 사용하였다. 이 입력된 자료를 이용하여 색 조화장품 브랜드의 자기시장잠식 분석을 위한 좌표점과 평가요인의 벡터를 구하여 biplot의 출력결과를 2 차원상의 positioning map으 로 나타낸 것이다.

본 연구에서는 positioning map이 복잡해지는 것을 피하고자 전 체 평가대안 색조화장품 브랜드에 대한 평가요소의 선호도 벡터를 Figure 1과 같이 도출하였다. Figure 1에 나타난 것과 같이 각 속성 벡터는 $\mathrm{X}$ 축과 $\mathrm{Y}$ 축의 교점을 중심으로 각 분면에 고르게 포진되어 있으며, 평가대안 이니스프리 색조화장품의 평가요소에 대한 좌표 를 보면 '확장된 패밀리 브랜드와 상호 연상되는 이 색조화장품이 가 격에 비해 품질이 뛰어나는 것의 차별화가 되는 것이 느껴진다,' '확 장된 패밀리 브랜드와 상호 연상되는 이 색조화장품은 내 피부에 맞 는 적합성을 가지고 있다가 차별화되는 것이 느껴진다,' '확장된 패 밀리 브랜드와 상호 연상되는 이 색조화장품의 심볼, 로고 디자인 그래픽이 차별화되는 것이 느껴진다,' 그리고 '확장된 패밀리 브랜 드와 상호 연상되는 이 색조화장품의 내용물 사용 시 용기의 기능성 이 좋다가 차별화되는 것이 느껴진다' 등이 강한 정체성을 가지고 
positioning 되어있다.

에이블씨엔씨 화장품의 확장된 패밀리 브랜드인 평가대안인 미샤 색조화장품과 어퓨 색조화장품의 경우 상호 연상되는 평가요소의 유사성으로 인해 상호 근접하게 붙어 있는 것으로 나타나 자기시장 잠식 현상이 이루어지고 있음을 보여주고 있다. 이들 확장된 패밀리 브랜드는 평가요소인 '확장된 패밀리 브랜드와 상호 연상되는 이 색 조화장품의 패키지 디자인의 유사성이 차별화되는 것이 느껴진다,' 확장된 패밀리 브랜드와 상호 연상되는 이 색조화장품의 색상이 세 련되고 우아함이 차별화되는 것이 느껴진다,' '확장된 패밀리 브랜드 와 상호 연상되는 이 색조화장품의 기능성 및 사용감이 좋다가 차별 화되는 것이 느껴진다,' 그리고 '확장된 패밀리 브랜드와 상호 연상 되는 이 색조화장품의 필감이 풍부하고 사용 정도가 우수함이 차별 화되는 것이 느껴진다' 등의 평가요소가 두 평가대안 색조화장품 브
랜드를 중심으로 eucledian distance가 상호 근접하게 positioning 되어있음을 알 수 있다.

Table 3과 Table 4는 Figure 1인 positioning map에서의 평가 대안과 평가요소의 X축과 $\mathrm{Y}$ 축에 대한 좌표 값을 나타내고 있으며 mind share는 소비자의 심상에 나타내고 있는 점유율로서 현재의 시장점유율 선행지표로 대체 가능하다(Kim, 2003; Song, 2018). Table 3의 mind share에서 가장 높게 나타난 것은 에뛰드하우스 색 조화장품(0.268)으로 나타났으며, 그 다음 순위가 이니스프리 색조 화장품(0.267)으로 나타났고, 에이블씨엔씨 화장품 그룹의 미샤 색 조화장품(0.232)과 어퓨 색조화장품(0.233)의 경우 평가대안 색조 화장품 브랜드 중 상대적으로 낮은 점유율과 포지션을 나타내고 있 는 것으로 도출되어졌다.

에이블씨엔씨 화장품 그룹의 확장된 패밀리 브랜드 미샤 색조화

Table ble 4. Evaluation element attribute value in positioning map

\begin{tabular}{|c|c|c|}
\hline \multirow{2}{*}{ Evaluation element } & \multicolumn{2}{|c|}{ Coordinate value of positioning map } \\
\hline & $\mathrm{X}$ axis & Y axis \\
\hline $\begin{array}{l}\text { 1. It is felt that these color cosmetics, interconnected with the extended family } \\
\text { brand, are differentiating themselves from the quality over the price. }\end{array}$ & -0.099 & 0.102 \\
\hline $\begin{array}{l}\text { 2. It is felt that it is differentiating the intention of the cost to be willing to pay for the } \\
\text { purchase of this high-functional color cosmetics interconnected with the extended } \\
\text { family brand. }\end{array}$ & -0.052 & -0.008 \\
\hline $\begin{array}{l}\text { 3. These color cosmetics, connected to the extended family brand, differentiate } \\
\text { themselves from activities for low-priced purchases (store and internet Shopping } \\
\text { mall Exploration activity). }\end{array}$ & -0.170 & -0.332 \\
\hline $\begin{array}{l}\text { 4. It is felt that these color cosmetics, which are interrelated with the extended family } \\
\text { brand, are differentiated from promotional activities such as purchasing during the } \\
\text { discount sale period or using discount coupons. }\end{array}$ & -0.041 & -0.066 \\
\hline $\begin{array}{l}\text { 5. It is felt that the quality of thiese color cosmetics alone is different from the price } \\
\text { interrelated with the extended family brand. }\end{array}$ & -0.048 & -0.020 \\
\hline $\begin{array}{l}\text { 6. It is felt that the overall color, usability, stability, and color persistence are } \\
\text { differentiated from these color cosmetics. }\end{array}$ & 0.236 & -0.051 \\
\hline $\begin{array}{l}\text { 7. The texture of these color cosmetics, interconnected with the extended family } \\
\text { brand, is rich and different. }\end{array}$ & 0.182 & -0.105 \\
\hline $\begin{array}{l}\text { 8. These color cosmetics, interconnected with the extended family brand, have } \\
\text { suitability for my skin and feel differentiated. }\end{array}$ & -0.262 & 0.076 \\
\hline $\begin{array}{l}\text { 9. The symbolic and logo design graphics of these color cosmetics, which are } \\
\text { interconnected with the extended family brand, can be felt to be differentiated. }\end{array}$ & -0.028 & 0.117 \\
\hline $\begin{array}{l}\text { 10. It is felt that the similarity of package design of these color cosmetics, } \\
\text { interconnected with the extended family brand, is different. }\end{array}$ & 0.134 & 0.040 \\
\hline $\begin{array}{l}\text { 11. The use of the contents of these color cosmetics, which are interrelated with the } \\
\text { extended family brand, makes it feel that the function of the container is good. }\end{array}$ & -0.059 & 0.124 \\
\hline $\begin{array}{l}\text { 12. These color cosmetic's container exterior design, interconnected with the } \\
\text { extended family brand, has a personality and feels the same and different from my } \\
\text { identity. }\end{array}$ & -0.012 & 0.065 \\
\hline $\begin{array}{l}\text { 13. It is felt that the skin condition improvement and strengthening function of this } \\
\text { color cosmetics, which are interrelated with the extended family brand, is most } \\
\text { consistent with the personal color (personal skin color) and is differentiated. }\end{array}$ & -0.036 & 0.008 \\
\hline $\begin{array}{l}\text { 14. It is felt that the colors of these color cosmetics, interconnected with the } \\
\text { extended family brand, are refined, elegant, and differentiated. }\end{array}$ & 0.104 & 0.010 \\
\hline $\begin{array}{l}\text { 15. The functionality and use of this color cosmetics, which are interconnected with } \\
\text { the extended family brand, is good and feels different. }\end{array}$ & 0.071 & 0.041 \\
\hline $\begin{array}{l}\text { 16. These color cosmetics-interconnected with the extended family brand-are rich } \\
\text { in writing, excellent in quality, and feel different. }\end{array}$ & 0.069 & 0.016 \\
\hline
\end{tabular}


장품과 어퓨 색조화장품 경우 두 브랜드 간의 eucledian distance 가 근접하게 붙어 있는 것으로 나타났으며 이들 두 브랜드를 중심 으로 가까이 positioning 되어 있는 평가요소의 유사성으로 인한 자 기시장잠식 현상이 예상되어지고 있음을 알 수 있어 각 평가대안에 대한 평가요소 간의 지각된 차별화가 요구된다. 아모레퍼시픽 화장 품 그룹의 이니스프리 색조화장품과 에뛰드하우스 색조화장품 경 우는 positioning map 상에서 두 평가대안 브랜드 간의 eucledian distance가 상대적으로 멀리 떨어져 있는 것으로 나타나 에이블 씨엔씨 화장품의 평가대안 색조화장품 브랜드보다 차별화가 이루 어져 있으며 유사성이 상대적으로 낮게 도출되는 것으로 나타나 positioning map 분석 결과에서는 자기시장잠식 현상이 발견되지 않았다.

\section{4. 색조화장품 브랜드 전환행렬 분석 결과}

색조화장품 시장에서 확장된 패밀리 브랜드의 자기시장잠식을 분 석하기 위해 색조화장품 사용 소비자를 대상으로 측정한 교차분석
을 이용한 브랜드 전환행렬 분석은 각 평가대안 색조화장품 브랜드 의 이탈고객률과 신규고객유입률 그리고 충성도와 브랜드 전환률을 파악하여 자기시장잠식과 경쟁 관계에 있는 색조화장품 브랜드로와 의 시장잠식 현상과 충성도도 파악하고자 하였다.

이러한 분석결과는 Table 2 의 자기시장잠식 측정을 위한 각 색조 화장품 브랜드 별 Bass 확산모형 추정 결과의 해석과 positioning map 분석 결과인 Table 3 , Table 4 의 분석 결과를 지지하는 유사한 결과로 나타났다. Table 5 와 Table 6 에서 본 연구 평가대안의 색조 화장품 브랜드 중 현재시장점유율이 가장 높게 나타난 브랜드는 이 니스프리 색조화장품 $22.0 \%$ 로 나타났으며, 가장 낮은 현재시장점 유율을 나타내고 있는 브랜드는 어퓨 색조화장품으로 $3.8 \%$ 의 현재 시장점유율을 나타내고 있는 것으로 나타났다. 이는 Table 3 의 분석 결과에서 이 브랜드의 mind share 분석 결과가 $23.3 \%$ 의 포지션으 로 낮게 도출된 것과 무관하지 않는 분석 결과 반응을 보인다.

그리고 Table 5 에서 이 두 브랜드의 향후 구매선택확률인 신규고 객유입률은 미샤 색조화장품의 경우 전체 연구 대상자 중 $8.4 \%$ 가 선

Tables 5. Cross analysis of currently used color cosmetics brands and intended-future-use cosmetics brands

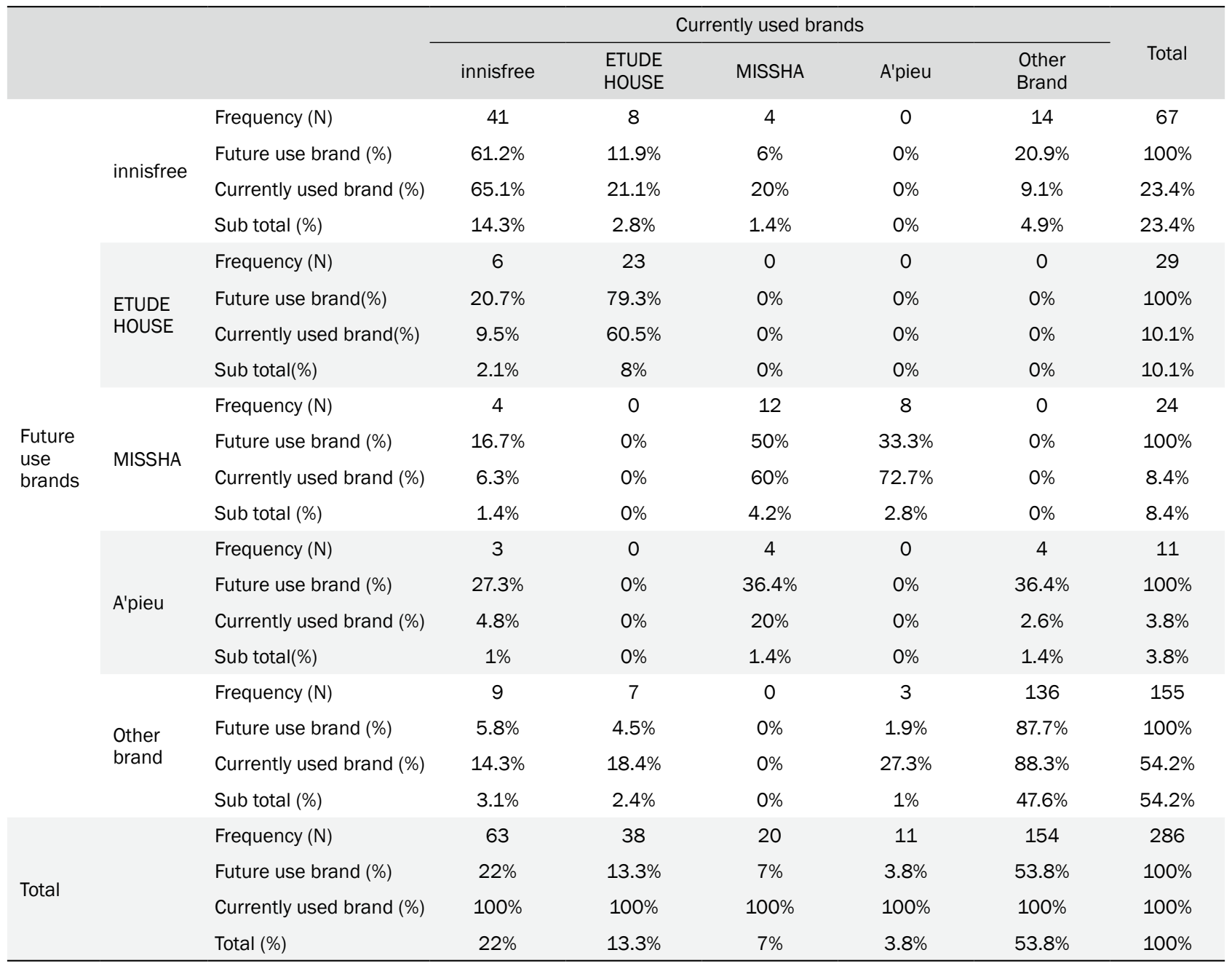


택의도를 밝혔다. 이들은 미샤 색조화장품의 $4.2 \%$ 충성고객과 어퓨 색조화장품에서 $2.8 \%$, 그리고 이니스프리 색조화장품에서 $1.4 \%$ 의 신규고객유입을 포함되는 것으로 나타났다. 어퓨 색조화장품의 경우 지속적으로 이용하겠다는 충성고객은 전혀 없으며 미샤 색조화장품 과 기타브랜드 색조화장품으로 전환하겠다는 이탈고객이 $100 \%$ 로 나 타났다. 그러나 미샤 색조화장품 $36.4 \%$ 와 이니스프리 색조화장품으 로부터 $27.3 \%$ 그리고 기타브랜드 색조화장품으로부터 $36.4 \%$ 의 유입 이 이루어져 총 11 명인 $3.8 \%$ 의 신규고객유입이 예상되나 전체 평가 대안 색조화장품 브랜드 중 가장 낮은 단기미래시장점유율로 나타났 다.

Table 5에서 가장 높은 미래 충성도를 보이는 것은 에뛰드하우스 색조화장품으로 $79.3 \%$ 의 미래 충성도를 보이는 것으로 나타났으며, 이니스프리 색조화장품의 경우 $61.2 \%$ 로 두 번째로 높게 나타났고, 미 샤 색조화장품의 경우 $50.0 \%$ 의 미래 충성도를 보이는 것으로 나타났 다. 평가대안 색조화장품 브랜드 중 상대적으로 가장 낮은 미래충성 도를 보이는 것은 어퓨 색조화장품으로 $0 \%$ 로 나타났다. 이는 자기가 현재 사용하고 있는 어퓨 색조화장품을 지속적으로 구매하겠다는 충 성고객 없이 전부 신규고객유입으로 구성되어지며, 전체 평가대안 색 조화장품 브랜드 중 단기미래시장점유율이 가장 낮은 $3.8 \%$ 를 유지하 는 것으로 나타났다. 미샤 색조화장품의 경우는 $40 \%$ 의 이탈고객이 예상되나 어퓨 색조화장품으로부터 $33.3 \%$ 와 이니스프리 색조화장품 으로부터 $16.7 \%$ 의 신규고객유입이 발생하여 단기미래시장점유율은 오히려 $1.4 \%$ 가 증가한 것으로 나타났다.

신규고객유입률이 가장 높게 나타난 것은 어퓨 색조화장품 브랜드 로 $100 \%$ 가 신규 고객인 것으로 나타났으며, 신규고객유입률이 가장 낮은 색조화장품 브랜드는 에뛰드하우스 색조화장품으로 $20.7 \%$ 의 신 규고객유입률을 나타내고 있으며 이들은 모두 이니스프리 색조화장 품에서 유입되는 것으로 나타나 자기시장잠식이 예상된다.

Table 5 로부터 시장잠식 현상을 예측하는 전체 브랜드의 이탈고 객과 신규고객유입률을 살펴보면 전체 $100 \%$ 에서 충성고객률을 빼 면 브랜드별 이탈고객률을 알 수 있는데 미샤 색조화장품 이탈고객률 $=100 \%-60 \%=40 \%$, 어퓨 색조화장품 이탈고객률=100\%-0\%=100\%, 에뛰드하우스 색조화장품 이탈고객률 $=100 \%-60.5 \%=39.5 \%$ 이며, 이 니스프리 색조화장품 이탈고객률 $=100 \%-65.1 \%=34.9 \%$ 이다. 가장
높은 이탈고객률을 나타내고 있는 브랜드는 어퓨 색조화장품이며, 그 다음이 미샤 색조화장품과 에뛰드하우스 색조화장품의 순위로 나타 났으며, 이니스프리 색조화장품의 경우는 $34.9 \%$ 의 이탈고객률을 보 이는 것으로 나타났다.

신규고객유입률은 단기미래시장점유율 전체 $100 \%$ 에서 향후 구매 의도 색조화장품 브랜드 중 \%를 빼면 되는데 신규고객유입률은 다음 과 같다. 미샤 색조화장품 신규고객유입률 $=100 \%-50 \%=50 \%$ 로 나 타났으나 어퓨 색조화장품 신규고객유입률 $=100 \%-0 \%=100 \%$ 로 나 타났고, 이니스프리 색조화장품 신규고객유입률=100\%-61.2\%= $38.8 \%$ 로 나타났으며, 에뛰드하우스 색조화장품 신규고객유입률 $=100 \%-79.3 \%=20.7 \%$ 로 나타났다.

이탈고객률이 $100 \%$ 로 가장 높게 나타난 어퓨 색조화장품 브랜드 의 경우 현재시장점유율 또한 가장 낮으며, 미래시장점유율 역시 가 장 낮게 나타났다. 그러나 신규고객유입률은 $100 \%$ 로 나타나 가장 높 은 신규고객유입률을 나타내고 있다. 이 브랜드의 경우 충성도가 지 극히 낮으며 $72.7 \%$ 의 고객이 패밀리 브랜드인 미샤 색조화장품으로 브랜드 전환을 나타내고 있어 높은 자기시장잠식 가능성이 예측된다.

Table 5 의 분석 결과를 요약한 Table 6 의 분석 결과로부터 에뛰드 하우스 색조화장품의 경우 이니스프리 색조화장품보다 이탈고객률이 높고 신규고객유입률은 낮은 것으로 나타났으며, 충성도가 이니스프 리 색조화장품보다 낮은 것으로 나타났다. 이러한 연구 결과는 어떤 기회가 주어진다면 언제든지 다른 색조화장품 브랜드로 전환 가능성 이 있음을 시사하고 있으며, 특히 $39.5 \%$ 의 이탈 고객 중 $53.3 \%$ 가 이 니스프리 색조화장품 브랜드로 전환하는 것으로 나타나 자기시장잠 식 현상 발생하는 것으로 나타났으며, 이러한 분석 결과는 Figure 1 의 positioning map 분석 결과와도 무관하지 않다.

\section{Conclusion}

본 연구는 색조화장품 시장에서 확장된 패밀리 브랜드에 대한 자기 시장잠식 분석으로 Bass 확산모형을 적용하여 자기시장잠식을 분석 하였으며, Bass 확산모형이 제공하지 못하는 것을 보완하고 검증하기 위해 또 다른 복수의 분석방법으로 biplot을 이용한 positioning map

Table 6. Market characteristics of evaluation alternative color cosmetics brands

\begin{tabular}{|c|c|c|c|c|c|c|}
\hline Brand name & & $\begin{array}{c}\text { Current market } \\
\text { share }(\%)\end{array}$ & $\begin{array}{c}\text { Future market } \\
\text { share }(\%)\end{array}$ & $\begin{array}{c}\text { Loyal } \\
\text { customer (\%) }\end{array}$ & $\begin{array}{c}\text { Leaving } \\
\text { customer (\%) }\end{array}$ & $\begin{array}{c}\text { New } \\
\text { customer (\%) }\end{array}$ \\
\hline \multirow{2}{*}{ Amore pacific cosmetic } & innisfree & 22.0 & 23.4 & 65.1 & 34.9 & 38.8 \\
\hline & ETUDE HOUSE & 13.3 & 10.1 & 60.5 & 39.5 & 20.7 \\
\hline \multirow{2}{*}{ Able C\&C cosmetic } & MISSHA & 7.0 & 8.4 & 60.0 & 40.0 & 50.0 \\
\hline & A'pieu & 3.8 & 3.8 & 0 & 100.0 & 100.0 \\
\hline Other brand & & 53.8 & 54.2 & 88.3 & 87.7 & 12.3 \\
\hline Total & & 100.0 & & & & \\
\hline
\end{tabular}


분석과 교차분석을 이용한 브랜드 전환행렬 분석을 동시에 실시하여 다음과 같은 연구 결과를 얻었다.

첫째, Bass 확산모형에 의한 자기시장잠식 분석 추정 결과는 평가 대상 색조화장품 브랜드 모두가 혁신계수보다 모방계수의 값이 더 높 게 나타나 자기시장잠식이 예상된다. 이는 저가화장품 시장에서의 자 기시장잠식을 연구한 Song (2020)의 연구와 결측값은 다르나 혁신계 수보다 모방계수의 값이 더 높게 나타나는 유사한 결과가 나타났다. 이러한 연구 결과는 새로운 브랜드가 전파되는 데 있어서 확산과정에 서 모방계수에 의하여 확산이 주도되는 특징이 있으며, 상대적으로 진입비율이 증가하게 되고 입소문 영향이 외부 영향보다 더 중요한 영향을 미치게 되며 모방계수의 값이 클수록 확산은 빠르게 일어나게 된다는 Sultan et al. (1990)의 연구와 Talukdar et al. (2002)의 연구 결과를 본 연구 분석 결과에서도 동일하게 적용할 수 있는 것으로 의 미할 수 있다.

둘째, positioning map 분석결과에서 아모레퍼시픽 화장품 그룹의 패밀리 브랜드인 평가대안 이니스프리 색조화장품과 에뛰드하우스 색 조화장품은 16 개 평가요소 측정항목의 차별화로 인해 확장된 브랜드 간의 유사성이 없어 자기시장잠식이 발견되지 않았으나 에이블씨엔씨 화장품 그룹의 패밀리 브랜드인 평가대안 미샤 색조화장품과 어퓨 색 조화장품은 평가요소인 '확장된 패밀리 브랜드와 상호연상되는 이 색 조화장품의 패키지 디자인의 유사성이 차별화되는 것이 느껴진다.' '확 장된 패밀리 브랜드와 상호연상되는 이 색조화장품의 색상이 세련되 고 우아함이 차별화되는 것이 느껴진다,' '확장된 패밀리 브랜드와 상 호 연상되는 이 색조화장품의 기능성 및 사용감이 좋다가 차별화되는 것이 느껴진다.' 그리고 '확장된 패밀리 브랜드와 상호 연상되는 이 색 조화장품의 필감이 풍부하고 사용 정도가 우수함이 차별화되는 것이 느껴진다' 등의 평가요소가 두 평가대안 색조화장품 브랜드를 중심으 로 eucledian distance가 상호 근접하게 붙어 있는 것으로 나타나 상호 연상되는 평가요소의 유사성으로 인해 자기시장잠식 현상이 이루어지 고 있음을 보여주고 있다. 따라서 이들 몰 정체성 된 상호 연상되는 평 가요소의 정체성 차별화를 통하여 자기시장잠식을 예방할 수 있을 것 이다.

셋째, 색조화장품의 자기시장잠식 측정을 위한 Table 5 와 Table 6 의 분석결과로부터 Table 2 의 자기시장잠식 측정을 위한 각 색조화장 품 브랜드 별 Bass 확산모형 분석결과의 해석과 positioning map 분 석 결과인 Table 3 , Table 4 의 분석결과를 지지하는 유사한 결과로 나 타났으며 평가대안 색조화장품 브랜드 모두 자기시장 잠식을 나타내 고 있는 것으로 판단된다.

그리고 본 연구 평가대안 색조화장품 브랜드 중 현재시장점유율과 미래시장점유율이 가장 높게 나타난 브랜드는 이니스프리 색조화장품 으로 나타났으며, 가장 낮은 현재시장점유율과 미래시장점유율을 나 타내고 있는 브랜드는 어퓨 색조화장품으로 나타났다. 그리고 브랜드 충성도가 가장 높은 색조화장품은 이니스프리 색조화장품이며 가장 낮은 충성도를 나타내고 있는 것은 어퓨 색조화장품으로 나타났다.
넷째, 색조화장품 시장에서 브랜드 믹스 확장전략으로 인한 발 생 가능한 자기시장잠식 현상의 분석을 위해 도입한 Bass 확산모형 과 positioning map 분석 그리고 교차분석을 이용하여 분석한 결과 아모레퍼시픽 그룹의 패밀리 브랜드인 이니스프리 색조화장품과 에 뛰드하우스 색조화장품의 경우 Bass 확산모형과 교차분석을 이용한 전환행렬 분석에서는 자기시장잠식이 발생하는 것으로 나타났으나 positioning map 분석에서는 두 브랜드 간의 eucledian distance가 상 대적으로 멀리 나타났다. 이는 자기시장잠식 현상을 무시하여도 좋은 것으로 보이며, 다른 평가대안 색조화장품 브랜드보다 유사성이 낮고 차별화가 잘 이루어진 것으로 나타났다.

에이블씨엔씨 화장품 그룹의 패밀리 브랜드인 평가대안 미샤 색조 화장품과 어퓨 색조화장품의 경우 자기시장잠식의 분석을 위해 도입 한 세 가지 분석방법 모두에게서 자기시장잠식 현상이 발생하는 것으 로 나타났다. 이러한 자기시장잠식 현상은 공격적 브랜드 확장전략 수립에 앞서 세심한 주의가 요구된다.

본 연구는 기업의 수익구조 개선을 위한 브랜드 확장 전략 계획의 수립과 효율적인 투자 정책을 위해 도움이 될 수 있는 생각과 함께 학 문적 연구 방법의 적용을 위해 부산지역 여대생을 중심으로 표본 구 성하여 수행하였다. 연구 결과를 일반화하기에는 제한점을 가질 수 있어 연구 지역과 대상을 확대 적용할 필요가 있으며, 향후 연구에서 는 자기시장잠식 연구를 위한 다양한 평가요소와 분석방법의 도입과 함께 다양한 검증 방법도 도입하여 분석결과에 대해 비교하고 검증하 는 후속적 연구가 이루어지기를 기대한다.

\section{Acknowledgements}

이 논문은 2018년 대한민국 교육부와 한국연구재단의 지원을 받아 수행된 연구임(NRF-과제번호)(NRF-2018S1A5B5A07072913).

\section{Author's contribution}

YJC and MJY performed data collection and analysis for the survey. SMS designed this project and wrote the manuscript with assistance from YJC and MJY.

\section{Author details}

Man Seok Song (Lecturer), Department of Advertising and PR, Tong Myong University, 428 Sinseon-rom, Nam-gu, Busan 48520, Korea; Yun-Jae Cho (Adjunct Professor), School of Start-up \& Assets Convergence (Marketing), Changwon National University, Changwonsi, Gyeongsangnam-do 51140, Korea; Mi Ju Yim (Adjunct Professor). College of Business Administration, Dong-A University, 225, Gudeok-ro, Seo-gu, Busan 49236, Korea. 


\section{References}

Aaker DA, Keller KL. Consumer evaluations of brand extensions. Journal of Marketing, 54: 27-41, 1990.

Bass FM. A new product growth model for consumer durables. Management Science, 15: 215-227, 1969.

Buday T. Capitalizing on brand extensions. Journal of Consumer Marketing, 6: 27-30, 1989.

Chandy RK, Tellis GJ. Organizing for radical product innovation: the overlooked role of willingness to cannibalize. Journal of Marketing Research, 35: 474487, 1998.

Chu SY. The impact of consistency of brand concept on consumer attitudes: Moderating roles of knowledge, involvement and typicality. Culinary Science \& Hospitality Research, 11: 18-29, 2005.

Collins-Dodd C, Louviere JJ. Brand equity and retailer acceptance of brand extensions. Journal of Retailing and Consumer Services, 6: 1-13, 1999.

Copulsky W. Cannibalism in the marketplace. Journal of Marketing, 40: 103-105, 1976.

Fishbein M. An investigation of the relationships between beliefs about an object and the attitude toward that object. Human Relations, 16: 233-240, 1963.

Jamieson LF, Bass FM. Adjusting stated intention measures to predict trial purchase of new products: a comparison of models and methods. Journal of Marketing, 26: 336345,1989

Jeong YH, Lee YJ, Kim KY. Compare of usage, purchase attribute and product quality between domestic and foreign color cosmetics: focus on the general public group and the beauty experts group. Journal of the Korean Society of Cosmetology, 22: 88-99, 2016.

John DR, Loken B, Joiner C. The negative impact of extensions: can flagship products be deluted? Journal of Marking Research, 62: 19-32, 1998.

Keller KL, Aaker DA. The effect of sequential introduction of brand extensions. Journal of Marketing Research, 29: 35-50, 1992.

Kim J. A study on design for enhancing brand awareness of color cosmetics brands. A Journal of Brand Design Association of Korea, 31: 311-320, 2014.

Kim K. Decision support system for evaluating positioning and repositioning strategy. Korea Marketing Review, 18:
73-92, 2003.

Kim KM, Kim JD. A study on requirement and degree of the satisfaction about cosmeceuticals of women. Journal of the Society of Cosmetic Scientists of Korea, 30: 571582, 2004.

Kim MH, Lee HJ. A study on brand trust of color cosmetics according to lifestyle of 20-40s woman consumer. Korean Journal of Human Ecology, 17: 1015-1026, 2008.

Kim TH, Shin HD. The economic impact of cannibalization strategy: a response to new technological breakthrough. Journal of Strategic Management, 11: 27-42, 2008.

Kim YS. Park BK. A study on the cannibalization of existing products according to the launch of new products: time series data analysis for new shoes products. Journal of Product Research, 36: 175-183, 2018.

Kirmani A, Sood S, Bridges S. The ownership effect in consumer responses to brand line stretches. Journal of Marketing, 63: 88-101, 1999.

Lee HJ. A study on the moisture cream container design of domestic cosmetic brands. A Journal of Brand Design Association of Korea, 14: 111-122, 2016.

Lee KE. A study on female undergraduates' color cosmetics purchase behavior and actual status of use. The Journal of the Korean Society of Knit Design, 11: 27-39, 2013.

Lee $\mathrm{KH}$, Jeong GY, Jang YW. The study on the effect of brand experience of color cosmetics on consumer-brand relationship and brand loyalty. The Journal of Business Education, 30: 59-90, 2016.

Lee SH, Chang YK. Fashion brand attachment and attitudes toward brand extension. Journal of the Korean Society of Clothing and Textiles, 31: 151-161, 2007.

Lee SH, Jung CY, Lee HW. Market segmentation cannibalization and competition in telecommunication services. Journal of the Korean Operations Research and Management Science Society, 21: 51-69, 1996.

Loken B, John DR. Diluting brand beliefs: when do brand extensions have a negative impact?. Journal of Marketing, 57: 71-84, 1993.

Lomax W, Hammond K, East R, Clemente M. The measurement of cannibalization. Journal of Product $\&$ Brand Management, 6: 27-39, 1997.

Martinez E, Montaner T, Pina JM. Brand extension feedback: the role of advertising. Journal of Business Research, 
62: 305-313, 2009.

Mason $\mathrm{CH}$, Milne GR. An approach for identifying cannibalization within product line extensions and multibrand strategies. Journal of Business Research, 31: 163170, 1994.

Moorthy KS, Png IPL. Market segmentation, cannibalization, and the timing of product introductions. Management Science, 38: 345-359, 1992.

Morein JA. Shift from brand to product line marketing: an efficient strategy for growth, product line marketing demands a coordinated marketing effort. Harvard Business Review, 53: 56-64, 1975.

Nijssen, E, Hillebrand B, Vermeulen PAM. Unraveling willingness to cannibalize: a closer look at the barrier to radical innovation. Technovation, 25: 1400-1409, 2005.

Park JS, Kwon HJ. Perception about makeup influence on man's makeup and their success. Journal of the Korea Convergence Society, 8: 231-237, 2017.

Park YE, Chin CH. Analysis of B.B cream used condition. Asian Journal of Beauty and Cosmetology, 8: 63-74, 2010.

Reddy SK, Holak SL. Bhat S. To extend or not to extend: success determinants of line extensions. Journal of Marketing Research, 31: 243-62, 1994.

Shin $\mathrm{CH}$. Research methods and a new multi-generation diffusion model for analyzing the cannibalization of telecommunications products. Industry and Management, 4:1-17, 1997.

Song MS. A study on the repositioning strategy for competitiveness of enterprise in low-cost cosmetics market. Asian journal of beauty and cosmetology, 16: 405-416, 2018.
Song MS. A study on the influence of brand extension portfolio strategy on cannibalization in low-cost cosmetics market. Asian Journal of Beauty and Cosmetology, 18: 65-77, 2020.

Sullivan M. Measuring image spillovers in umbrella branded products. Journal of Business, 63: 309-329, 1990.

Sultan F, Farley JU, Lehmann DR. A meta-analysis of applications of diffusion models. Journal of Marketing Research, 27: 70-77, 1990.

Tait B. Do gaps in marketing theory make new brands fail?. AdMap, 36: 40-43, 2001.

Talukdar D, Sudhir K, Ainslie A. Investigating new product diffusion across products and countries. Marketing Science, 21: 97-114, 2002.

Tauber EM. Brand leverage: strategy for growth in a cost controlled world. Journal of Advertising Research, 28: 26-30, 1988.

Urban GL, Hauser JR. Design and marketing of new products. Pearson, London, pp464-489, 1993.

Varshney NK. Analysis of market cannibalization. International Journal of Advanced Technology in Engineering and Science, 4: 177-181, 2016.

Völckner F, Sattler H. Drivers of brand extension success. Journal of Marketing, 70: 18-34, 2006.

You KS, Choi MK. The analysis of competition structure in business data service market using henry model and suggestion for competitive strategies. The Journal of Korea Information and Communications Society, 26: 280-291, 2001.

Yu HK. Images of k-beauty and Korean cosmetic brands perceived by Vietnamese women. Journal of Brand Design Association of Korea, 14: 219-230, 2016. 


\section{국문초록}

\section{색조화장품 브랜드 확장과 자기시장잠식에 대한 연구}

송만석 ${ }^{1 *}$, 조윤재 ${ }^{2}$, 임미주 $^{3}$

${ }^{1}$ 동명대학교 광고홍보학과, 부산, 한국

${ }^{2}$ 창원대학교 미래융합대학, 경상남도 창원시, 한국

${ }^{3}$ 동아대학교 경영학과, 부산, 한국

목적: 최근 국내 색조화장품 시장 규모와 수요의 평균 성장률이 점차 증가하고 있으며, 색조화장품 브랜드간의 경쟁 또한 심화되고 있다. 이러한 가운데 브랜드 포트폴리오 확장전략으로 하향확장된 대기업 계열 화장품 기업들은 새로운 색조화장품을 개발하여 시 장에 출시하고 있으나 그 성과에 대한 실효성이 의문시되고 있다. 잘못된 브랜드 확장은 기존 브랜드에 대한 전반적인 이미지의 실 패와 함께 패밀리 브랜드간의 자기시장잠식 현상 발생하여 기업 전반에 걸친 매출액 감소와 함께 시장효율이 저하되는 치명적인 손 실을 갖는 최악의 상황을 맞게 된다. 방법: 본 연구에서는 색조화장품 시장에서 모기업을 중심으로 확장된 패밀리 화장품 기업에서 출시한 색조화장품의 자기시장잠식 현상을 파악하기 위해 Bass 확산모형과 지각도 분석 그리고 교차분석을 도입하여 자기시장잠 식 분석을 실시하고자 한다. 색조화장품을 사용하고 있는 여대생을 대상으로 286부의 설문지를 수집하여 SPSS사의 통계 패키지 프 로그램으로 빈도분석을 실시하여 인구통계적 분석과 biplot 분석을 실시하여 지각도 분석을 실시하였으며, 그리고 교차분석을 실시 하여 평가대안 색조화장품 브랜드에 대한 충성도, 전환의도, 이탈율, 미래시장 점유율 분석과 함께 자기시장잠식 현상을 파악하였 다. 그리고 연구 대상 평가대안 기업의 시계열 자료를 이용하여 Bass 확산모형 분석을 실시하여 자기시장잠식을 분석하였다. 결과: 자기시장잠식 분석을 위한 Bass 확산모형의 분석결과 두 개의 패밀리 그룹에서 모두 발생되어지는 것으로 나타났으며, 이들 모두 의 모방계수의 값이 혁신계수의 값보다 높게 나타나 진입비용이 증가하게 되며 신상품 전파에 있어서 구전의 영향력이 높아진다고 할 수 있다. 그리고 지각도 분석에서는 에이블씨엔씨 화장품의 미샤와 어퓨의 색조화장품 브랜드에서만 자기시장잠식 현상이 발생 하는 것으로 나타났다. 그러므로 이들 평가대안으로부터 근접하게 붙어 있는 평가요소의 차별화를 통하여 자기시장잠식 현상을 최 소화하여야 할 것이다. 교차분석에서도 평가대안 모두에게서 자기시장잠식 현상이 발생하는 것으로 나타났으며, 어퓨의 경우 가장 낮은 충성도를 보이고 있었으며 신규고객유입률은 높은 것으로 나타났다. 이니스프리의 경우 현재시장점유율뿐만 아니라 단기미래 시장점유율도 가장 높은 것으로 나타났으며 충성고객률 또한 가장 높은 것으로 나타났다. 결론: 색조화장품 시장에서 자기시장잠 식 분석을 위해 실행한 본 연구에서 평가대안으로 선정한 두 개의 패밀리 그룹에서 자기시장잠식이 발생하는 것으로 분석되어져 나 타났다. 자기시장잠식 분석을 위해 잘 알려져 있는 Bass 확산모형의 도입과 함께 보완적 분석방법으로 도입한 대응일치 분석을 이 용한 지각도 분석과 교차분석을 이용한 자기시장잠식 분석은 본 연구에서만 아니라 다른 연구 분야에서도 유용하게 적용할 수 있을 것으로 기대할 수 있다. 이러한 색조화장품 시장에서의 자기시장잠식 분석을 위한 연구 분석 결과는 격심한 경쟁구조에서 확장된 브랜드 포트폴리오의 성과 측정, 신제품 출시뿐만 아니라 브랜드의 신규시장 진출, 경쟁브랜드와의 시장경쟁구조분석 그리고 자기 시장잠식 방어전략의 제시 등 다양한 분야에 적용 가능한 시사점을 제시할 수 있다.

핵심어: 색조화장품, 자기시장잠식, Bass 확산모형, 지각도, 교차분석

이 논문은 2018년 대한민국 교육부와 한국연구재단의 지원을 받아 수행된 연구임( $\mathrm{NRF}-$ 과제번호) $(\mathrm{NRF}-$ 2018S1A5B5A07072913).

\section{참고문헌}

김강미, 김주덕. 우리나라 여성들의 기능성화장품에 대한 요구 및 만족도 연구. 대한화장품학회지, 30: 571-582, 2004. 김근배. 포지셔닝과 재포지셔닝 전략의 평가를 위한 의사결정지원 시스템. 마케팅연구, 18: 73-92, 2003.

김미현, 이혜주. 여성 소비자의 라이프스타일에 따른 색조화장품의 브랜드 신뢰에 관한 연구: $20 ~ 40$ 대 소비자를 중심으 
로. 한국생활과학회지, 17: 1015-1026, 2008.

김윤석, 박병기. 신제품 출시에 따른 기존 제품 자기잠식에 대한 실태 연구: 신발 제품에 대한 시계열 데이터 분석. 상품학

연구, 36: 175-183, 2018.

김진영. 색조화장품의 브랜드 이미지 강화를 위한 디자인 연구. 브랜드디자인학연구, 12: 311-320. 2014.

김태하, 신형덕. 신기술 개발에 대처하기 위한 자기시장잠식의 의사결정. 전략경영연구, 11: 27-42, 2008.

박영은, 진정화. 비비크림의 사용현황 조사. 아시안뷰티화장품학술지, 8: 63-74, 2010.

박장순, 권혜진. 성공에 미치는 메이크업의 영향력 및 메이크업에 대한 사용자의 인식. 한국융합학회논문지, 8: 231-237,

2017.

송만석. 저가화장품 시장에서의 기업 경쟁력 강화를 위한 리포지셔닝 전략에 관한 연구. 아시안뷰티화장품학술지, 16 :

405-416, 2018.

송만석. 저가화장품 시장에서의 브랜드 확장 포트폴리오 전략이 Cannibalization에 미치는 영향에 관한 연구. 아시안뷰티

화장품학술지, 18: 65-77, 2020.

신창훈. 통신상품 자기시장잠식 분석을 위한 방법론 고찰 및 확산모형. 산업과 경영, 4: 1-17, 1997.

유광숙, 최문기, Hendry Model을 활용한 기업용데이터서비스시장의 경쟁구조 분석 및 전략 제언. 한국통신학회논문지,

26: 280-291, 2001.

유혜경. 베트남 여성들이 지각하는 K-beauty와 한국화장품 브랜드 이미지. 브랜드디자인학연구, 14: 219-230, 2016.

이경은. 여대생의 색조화장품 구매행동 및 사용실태. 패션과 니트, 11:27-39, 2013.

이경희, 정갑연, 장용운. 색조화장품 브랜드 경험이 소비자-브랜드 관계 및 브랜드 충성도에 미치는 영향에 관한 연구. 상

업교육연구, 30: 59-90, 2016.

이상호, 정충연, 이현우. 통신상품간 시장잠식현상과 경쟁도입의 효과 분석. 한국경영과학회지, 21: 51-69, 1996.

이승희, 장윤경. 패션 브랜드 애착이 확장된 브랜드 태도에 미치는 영향. 한국의류학회지, 31: 151-161, 2007.

이현주. 국내 화장품 브랜드별 수분크림 용기디자인에 관한 연구: 아모레퍼시픽을 중심으로. 브랜드디자인학연구, 14:

111-122, 2016.

정영희, 이윤진, 김기영. 국내산과 국외산 색조화장품의 사용실태, 구매속성과 제품 품질에 대한 인식 비교: 일반인 집단과 뷰티 전문가 집단 중심으로. 한국미용학회지, 22: 88-99, 2016.

추상용. 확장 외식 브랜드에 대한 개념 일치성과 고객의 지식이 소비자 태도에 미치는 영향 연구. 한국조리학회지. 11:

18-29, 2005. 


\section{中文摘要}

\section{彩色化妆品品牌扩张与自我市场侵占研究}

宋晚碩 ${ }^{*} ，$ 趙允載 ${ }^{2}$, 林美珠 ${ }^{3}$

东明大学广告宣传系，釜山，韩国

2昌原大学未来融合大学, 庆尚南道昌原市, 韩国

${ }^{3}$ Dong-A大学经营学科, 釜山, 韩国

目的: 不正确的品牌扩张可能会导致现有品牌的形象失败, 并在家族品牌之间造成虫食。它可能会减少销售并降 低市场效率，从而带来最坏情况下的致命损失情况。方法: 本研究使用Bass扩散模型，定位图分析和相食化分 析, 通过引入交叉分析来了解有色化妆品领域的自我市场侵占现象。具体来说, 我们专注于一家大型化妆品公 司的子公司。我们对286位使用彩色化妆品的女大学生进行了问卷调查。然后, 我们使用“社会科学统计软件包” 进行了频率分析, 以进行人口统计分析和双线图分析。我们还进行了定位图分析和交叉分析, 以了解彩色化妆 品的品牌忠诚度, 转让意向, 脱离率, 未来市场份额率和同类相食现象。结果: 用于自我市场侵蚀分析的巴斯扩 散模型的分析结果, 发现在两个家庭群体中都发生了这种情况。根据定位图分析, 蚕食现象仅发生在Able C \& C 化妆品品牌的MISSHA和A'fieu彩色化妆品上。所有的交叉分析估计替代品都显示出自我市场侵占现象。结论: 这些结果对在竞争激烈的市场中扩大品牌组合绩效的措施, 推出新产品, 在新市场中推出新品牌, 分析具有竞 争性品牌的市场竞争结构以及制定防御自我市场侵占的策略具有重要意义。

关键词: 彩色化妆品, 自我市场侵占, Bass扩散模型, 定位图分析, 交叉分析 
